\title{
A LOCATION MODEL OF A TRUST OF PUBLIC FIRMS ${ }^{1}$
}

\author{
Xiao Feng ${ }^{2}$, Peter Friedrich ${ }^{3}$ \\ Tongji University, University of Tartu
}

\begin{abstract}
The decision oriented theory of the public firm (Feng, Friedrich 2013) becomes extended. The authors consider that sometimes public firms compete horizontally as well. This can be due to competition among the public owners (e.g. municipalities) considering location choices for public firms they own, or public firms competing against each other. We mention some results related to the first type of competition and we refer to how the literature on location choices under oligopolic conditions could be referred to within the framework of our basic approach. One approach by Cornes and Hartley (2001) also allows modelling the establishment of joint ventures and their location choices. The basic model of the public firm is used to provide insight into the location choices of a trust of public firms. The trust exhibits coordination at three levels via the politically-oriented decision-making body of the public owner, the trust's headquarters and subsidiary public firms. The resulting model illustrates the interplay of different decisionmakers and the effects of the coordinating activities. The first attempts to formulate a public firm decision-making oriented location theory exist.
\end{abstract}

Keywords: location theory, public firm theory, industrial location theory, competition among public firms, principal agent, trust of public firms

JEL Classification: D61, D73, HO, H11, H42, H70, D61, D73, L32, N9, R14, R53

\section{Introduction}

The theory of public firm developed on the basis of a public firm theory (Feng, Friedrich 2013) concentrated on locational choice of one public enterprise and vertical co-ordination by its owner. However, the location choices are also influenced through competition and co-ordination with other public enterprises. These firms may have different public owners, e.g. municipalities, or may be subsidiaries of a trust of public firms. How the decision oriented public firm location theory and competition theory concerning public firms can be linked to

\footnotetext{
${ }^{1}$ The authors acknowledge the support of the Estonian Science Foundation's grant 8580 and target financing of the Estonian Ministry of Education and Research 0180037s08.

2 Prof. Dr. Xiao Feng, director of Sino-German College of Applied Sciences (CDHAW), Training Building, Jiading Campus, Tongji University, 4800 Cao An Highway, Shanghai, P. R.China (201804), Tel.: 0086 (0)21 6958 4732, Fax.: $00 \quad 86$ (0)21 6958 9621, fengxiao@tongji.edu.cn

3 Prof. Dr. h.c. Peter Friedrich, senior researcher, Faculty of Economics and Business Administration, University of Tartu, Narva Rd. 4, 51009 Tartu, Estonia, Tel. 003727376333 , Fax 003727376327, Peter@mtk.ut.ee
} 
location theory of a public firm is shown in this article ${ }^{4}$. The research task concerns how location decisions of public firms get coordinated and is influenced by horizontal competition. This task leads to the following questions:

- How can models of horizontal competition among public firms and owners of public firms be extended to location theory?

- How to integrate the location theory of one public firm into the horizontal and vertical co-ordination within a trust of public firms?

The competition theories and related location theories are not repeated in this article in detail. They are offered in literature. Here the relation between location theory and the decision oriented theory of one public firm is stressed

The authors devote the second section to the incorporation of the theory of the public firm into location theory approaches or of competition theory into some approaches of public office location theory. A model Location model of a public trust follows in the third section. Some hints for further development of this kind of location theory of public firms follows in the conclusive section.

\section{Public firms in horizontal competition}

A competitive localization situation exists if municipalities compete on the basis of the establishment of municipal firms (e.g. wellness swimming pools, convention halls). This can be formulated as a game where two municipalities are the players, and the municipalities have gains (F) or losses to be avoided or votes. The strategies can be locations. The payoff at the location may result from our model above or in the case of votes by applying the extended Pelzman model (Feng, Friedrich 2013). However, if the public firms themselves compete as well, the payoff is additionally determined by a duopoly solution embedded in the model above (Friedrich 1988). For each pair of locations, the solution above is determined at a given price (solution above) for the competitor. Following this assumption a Launhardt-Hotelling solution is elaborated to yield the payoffs. There can be several solutions in dominant strategies, equilibrium points, absolute equilibrium points, and so on (Friedrich, 1976 pp. 237 and 287). The solutions for the duopolies and municipal competition provides other results such as employment, prices, outputs, votes, use of land, and so on, and different payoff matrices result. If the municipal firms export to another municipality as well, positive payoffs may lead to a movement of location in the direction of the city limit between the two municipalities. If the policy is to prevent losses, the locations tend to move in the opposite direction. If both municipalities use simple indicators, such as jobs as payoffs, they are in severe conflict. The conflict may reduce if the payoffs are different or more sophisticated resulting from a utility analysis including several goals.

This is obvious in the case of attracting a public firm of a non-municipal public body (e.g. a federal or provincial firm) or if such a firm is considering a move to a

\footnotetext{
${ }^{4}$ The reader should also turn to the development of public firm location theory presented in the article: Basic Approaches to a Location Theory of One Public Firm (Feng, Friedrich 2013).
} 
competing municipality. In the first and the second case, a game can be formulated, where the strategies are locations offered to the firm or its public decision-maker, where the public decision-maker chooses a location according to its preferences among the locations offered and where payoffs consequently result. The individual payoffs can be delineated using the model above or through other information. If both players use simple indicators such as jobs, a constant sum game or a zero-sum game in the case of a resettlement can result. Then this may lead to a minimax solution in terms of location. That is also true if, in both cities, the same parties govern the city, and they expect to strengthen their power through the settlement (e.g. immigration of additional party members). However, if the local governments in one of the cities fear an influx of inhabitants that will not vote for the ruling party, this city will not be interested in the settlement of the public firm. The payoffs in the game change totally, and this city offers no location to the public firm or a very unfavourable one; therefore, leaving the settlement to the competitor.

If there is political competition between the two parties in a community to form the local government by offering locations, and if there are three different groups of voters, a vote paradox (Mueller 2002) may occur. Under these circumstances, the party which offers the voters first looses votes because the opposite party always finds an alternative location to beat the political competitor. Therefore, the resulting location is determined by the sequence of location campaigns.

Sometimes several municipalities want to establish a joint public firm. They expect positive payoffs particularly if the common location is chosen within their territory. If there are three municipalities with equal decision-making strength (e.g. through size, population, voters, financial means) the high school problem results (Isard, Smith, Isard, Tung, Dacey 1986). Two of the municipalities may form a coalition so as to locate the public firm near these two municipalities. However, the third municipality may destroy the coalition by offering to form a new coalition with one of the decision-makers. In this case, the decision-maker who was excluded may disrupt this coalition by making a counter offer. The coalition process creates a cycle and a rule must exist to stop the negotiations in order to find a location (e.g. a location near all three municipalities).

Another extension of an approach developed by Cornes and Hartley (2001) makes it possible to determine the number of municipalities joining in the formation of a public enterprise at different possible locations. If we consider the total sum of resources needed at location " $a$ " using $X_{a}$, we can name the share of municipality $i$ using $\mathrm{x}_{\mathrm{ia}} / \Sigma \mathrm{x}_{\mathrm{ja}}$. The utility gains $\mathrm{c}_{\mathrm{ia}}$ from the establishment of the public firm, increasing with the growing share of municipality $i$ in $E_{a}$, where the dis-utilities $b_{\text {ia }}$ are related to its share ${ }^{5}$. An optimal share function is determined for each

\footnotetext{
${ }^{5}$ There are $\mathrm{n}$ municipalities $\mathrm{i}$ which could form a joint enterprise at location a. The utility function of town $i$ is:

(1) $\mathrm{u}_{\mathrm{ia}}=\mathrm{c}_{\mathrm{i}} \cdot\left(\mathrm{x}_{\mathrm{ia}} / \sum \mathrm{x}_{\mathrm{ja}}\right)-\mathrm{b}_{\mathrm{ia}} \cdot \mathrm{x}_{\mathrm{ia}}$; $\mathrm{c}_{\mathrm{ia}}$ positive evaluation, bi opportunity costs, $\mathrm{x}_{\mathrm{ia}}$ resources from i, $\mathrm{X}_{\mathrm{a}}$ total resources for the public enterprise,

Municipalities apply autonomous strategy and determine an optimal response function.
} 
municipality. As the sum of all shares must achieve 1, we can add all the share functions to a total function. Where this function equals 1 , we find a solution and determine the number of municipalities engaged in the cooperation (c.f. Figure 10). If the utility wi becomes larger than the added share, the function gets less steep and moves to the right. That means there will be less municipalities joining the public firm; however, the utility of the participating towns and the total investment sum turns out to be higher if a more costly firm and location is chosen. The same is true if the opportunity costs of finance shrink. The opposite development occurs if the utilities of the municipalities decrease or opportunity costs of finance increase. These models are more useful for explaining which location is chosen and which communities cooperate. However it does not help identify the most desirable location from the point of view of society. There must be an additional welfare function to detect the optimal social location for public firms from the different locations achieved from evaluations of the municipalities involved. Then vertical evaluation and an element of competition is introduced.

Other models refer to identifying a location for hazardous facilities, where such a function is introduced by requiring efficient - mostly cost minimal sites. The externalities extend beyond the border of the community selected as a site. A pattern of compensation payments among the communities allowing a location is developed (Waehrer 2003). For some models, it is assumed, as in public facilities location theory, that costs should be minimized. The costs for locations within a community are possessed by the community. The costs associated with a location outside the community border are considered public information. Cost minimal locations are to be determined (Kunreuther, Kleindorfer 1986; Kunreuther, Kleindorfer, Knez, Yasick 1987). When considering the negative effects of a site, the tendency of a community prevails to locate the facility near the border (Ingberman 1995). Crossborder effects can also be considered (Richardson, Kunreuther, 1993) where external effects occur in non-neighbouring municipalities as well. Some authors (Armstrong, 1996; Bernheim, Whinston 1986; MCAfee, McMillan 1988; McAfee, McMillan, Whinston 1989; Rochet, Choné 1998; Jehiel, Moldevanu 1996; Frey, OberholzerGee 1996; Frey F. Oberholzer-Gee, Eichenberger 1996; Jehiel, Moldovanu, Stacchetti 1999; Williams 1999) develop or discuss mechanisms to compensate decision-makers involved in such a way that a cost minimal site is going to be chosen. There are other mechanisms that are directly related to public firms and concern investment (Friedrich 1969, 1976), or are debated in the literature on participating in private public partnerships (Grimsey, Lewis 2004) or the literature on built up growth pools and clusters in transformation processes (Friedrich, Feng 1998). The location problem for public firms is embedded in two ways. There are municipalities competing horizontally for or against a location. The cost functions dealt with in the models may be interpreted as the difference between turnover and cost, net-benefits, utilities and political returns (votes), thus making it possible to introduce the location problem as discussed here.

The optimal solution that means the optimal number of communities and an adequate volume for $\mathrm{Xa}$ is determined where the sums of the values of the optimal respond strategies adds up to one. 

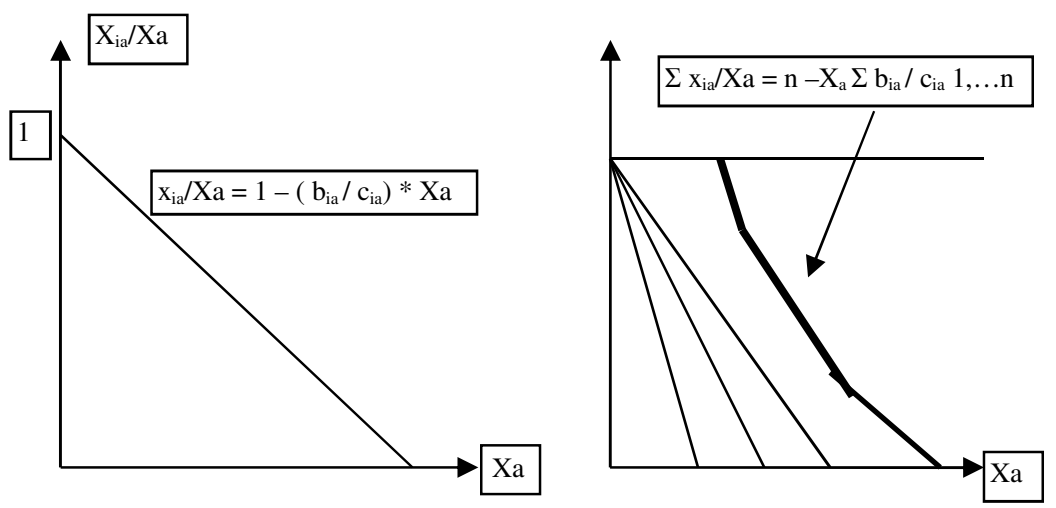

Figure 10. Share function solution for location a (compiled by the authors).

The problem is that most of these contributions try to prove that there are siting policies and compensation schemes that can determine optimal locations (Waehrer 2003); however, they do not come up with rules that can be applied in real situations. There are many additional legal and economic restrictions that do not allow for compensations (i.e. gifts among municipalities and horizontal fiscal equalization among municipalities are not allowed), and difficulties exist in organizing and participating in auctions etc. Moreover, most of these models consider a mix of vertical and horizontal competition between municipalities.

\section{Location model for a trust of public firms}

The interaction between vertical and horizontal factors of competition as well as economic and political factors with respect to selecting a location for public firms is demonstrated using a three-level model. It consists of public firms at the bottom belonging to a public trust. There is public firm $\mathrm{j}$ in region $\mathrm{j}$. The firms are cocoordinated financially by the headquarters of the public trust that receives financial means for investment through the public owner (e.g. ministry of finance of a government). Voters live in region $\mathrm{j}$ on whose voting behaviour the government depends. Voters are sensitive to the output of firm $j$ and the financing of budget $\mathrm{D}$. The size of fixed capital $\mathrm{Aj}\left(\mathrm{s}_{\mathrm{j} 1}, \mathrm{~s}_{\mathrm{j} 2}\right)$ for firm $\mathrm{j}$ equals budget $\mathbf{D}_{\mathrm{j}}$ to cover fixed costs $K_{\mathrm{Fj}}$. The fixed costs also depend on the location $\mathbf{s}_{\mathbf{j} 1}, \mathrm{~s}_{\mathbf{j} 2}$ of the public firm. We assume a production function (10) in Table 1, where the production depends on $\mathrm{Aj}$ and on Labour $\mathrm{L}_{\mathrm{j}}$ and on material $\mathrm{C}_{\mathrm{j}}$. Then there is a demand function (11) and the self-financing of the variable costs (equation (12)). The utility of management depends on output $\mathrm{X}_{\mathrm{j}}$ and labour $\mathrm{L}_{\mathrm{j}}$ (equation (13)). The maximization of the utility of management under the restriction of the self-financing of variable costs (14) yields first order conditions referring to directions 1 and 2. The indifference curves for the management are shown in Figure 11. 


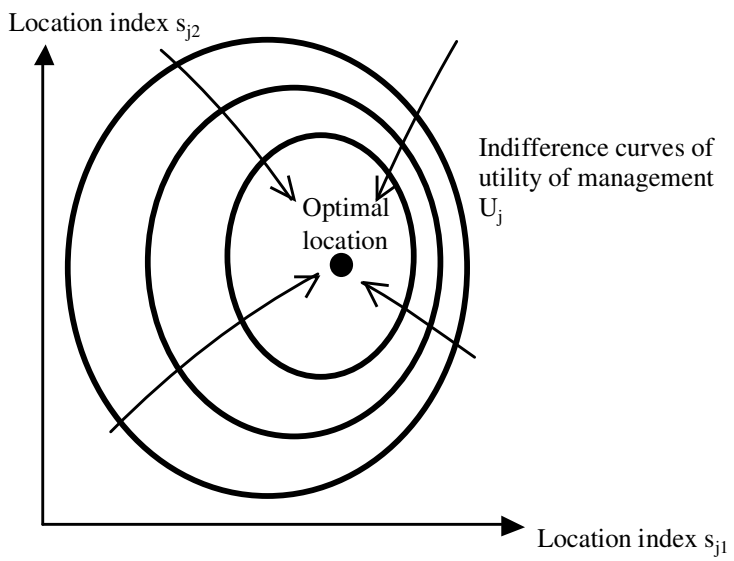

Figure 11. Optimal location of one public firm belonging to the trust (compiled by the authors).

The relation of the marginal changes to fixed costs by location variations in different directions equals the proportion of the subsequent differences. They comprise the variation in wage costs minus the variation in production volume multiplied by the marginal turnover. This is equivalent to the rule that the rate of marginal utilities by moving equals the proportion of marginal gross profits ${ }^{6}$.

The relation mentioned above also exists if the location is given and optimal output is determined. The proportion of marginal utilities to factor variations equals the proportion of marginal gross profits. The implied relation between input $C_{j}$ and $L$ is shown in (14.2) as are the terms for $C$ and $L$. The optimal solution for Output $\mathbf{X}$ is shown in (14.3) and the relation between $\mathrm{X}_{\mathrm{j}}$ and the fixed factor $\mathrm{A}_{\mathrm{j}}$ (fixed costs $\mathrm{K}_{\mathrm{Fj}}$ and budget $\mathrm{D}_{\mathrm{j}}$ ) is demonstrated in Figure 12. Equation (14.4) derives the utility of management at a given location.

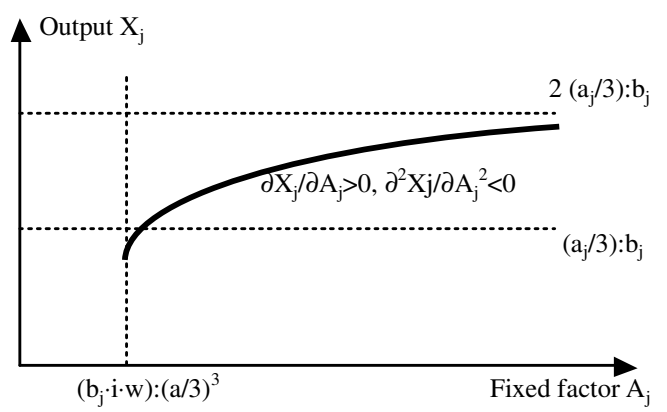

Figure 12. Development of the output if the fixed factor is varied (compiled by the authors).

\footnotetext{
${ }^{6}$ Look also section IV.
} 
Table 1. Equations concerning public firm $\mathrm{j}(=1,2)$

(10) Production function

$X_{j}=A_{j}\left(s_{j 1}, s_{j 2}\right) \cdot L_{j} \cdot C_{j}$,

while $\mathrm{A}_{\mathrm{j}}\left(\mathrm{s}_{\mathrm{j} 1}, \mathrm{~s}_{\mathrm{j} 2}\right)=\mathrm{K}_{\mathrm{Fj}}=\mathrm{D}_{\mathrm{j}}$

(11) Price-demand function

$P_{j}=a_{j}-b_{j} \cdot X_{j}=a_{j}-b_{j} \cdot A_{j} \cdot L_{j} \cdot C_{j}$

(12) Self-financing of variable costs

$\mathrm{w}_{\mathrm{j}}\left(\mathrm{s}_{\mathrm{j} 1}, \mathrm{~s}_{\mathrm{j} 2}\right) \cdot \mathrm{L}_{\mathrm{j}}+\mathrm{i} \cdot \mathrm{C}_{\mathrm{j}}=\mathrm{P}_{\mathrm{j}} \cdot \mathrm{X}_{\mathrm{j}}$

(13) Utility of management

$\mathrm{U}_{\mathrm{j}}=\mathrm{L}_{\mathrm{j}} \cdot \mathrm{X}_{\mathrm{j}}$

(14) Utility maximization

Max! $U_{j}=L_{j} \cdot X_{j}=A_{j} \cdot L_{j}^{2} \cdot C_{j}$, while $\left(a_{j}-b_{j} \cdot A_{j} \cdot L_{j} \cdot C_{j}\right) \cdot A_{j} \cdot L_{j} \cdot C_{j}=w_{j} \cdot L_{j}+i \cdot C_{j}$;

Lagrange-Function:

$$
L=\mathrm{A}_{\mathrm{j}} \cdot \mathrm{L}_{\mathrm{j}}^{2} \cdot \mathrm{C}_{\mathrm{j}}+\lambda \cdot\left[\left(\mathrm{a}_{\mathrm{j}}-\mathrm{b}_{\mathrm{j}} \cdot \mathrm{A}_{\mathrm{j}} \cdot \mathrm{L}_{\mathrm{j}} \cdot \mathrm{C}_{\mathrm{j}}\right) \cdot \mathrm{A}_{\mathrm{j}} \cdot \mathrm{L}_{\mathrm{j}} \cdot \mathrm{C}_{\mathrm{j}}-\mathrm{w}_{\mathrm{j}} \cdot \mathrm{L}_{\mathrm{j}}-\mathrm{i} \cdot \mathrm{C}_{\mathrm{j}}\right]
$$

$\begin{aligned} &(14.1) \partial \mathrm{L} / \partial \mathrm{s}_{\mathrm{j} 1}=0 \\ & \partial \mathrm{L} / \partial \mathrm{s}_{\mathrm{j} 2}=0\end{aligned}, \frac{\partial \mathrm{A}_{\mathrm{j}} / \partial \mathrm{s}_{\mathrm{j} 1}}{\partial \mathrm{A}_{\mathrm{j}} / \partial \mathrm{s}_{\mathrm{j} 2}}=\frac{\left(\partial \mathrm{w}_{\mathrm{j}} / \partial \mathrm{s}_{\mathrm{j} 1}\right)-\left(\partial \mathrm{A}_{\mathrm{j}} / \partial \mathrm{s}_{\mathrm{j} 1}\right) \cdot\left(\mathrm{a}_{\mathrm{j}}-2 \cdot \mathrm{b}_{\mathrm{j}} \cdot \mathrm{A}_{\mathrm{j}} \cdot \mathrm{L}_{\mathrm{j}} \cdot \mathrm{C}_{\mathrm{j}}\right) \cdot \mathrm{C}_{\mathrm{j}}}{\left(\partial \mathrm{w}_{\mathrm{j} 2} / \partial \mathrm{s}_{\mathrm{j}}\right)-\left(\partial \mathrm{A}_{\mathrm{j}} / \partial \mathrm{s}_{\mathrm{j} 2}\right) \cdot\left(\mathrm{a}_{\mathrm{j}}-2 \cdot \mathrm{b}_{\mathrm{j}} \cdot \mathrm{A}_{\mathrm{j}} \cdot \mathrm{L}_{\mathrm{j}} \cdot \mathrm{C}_{\mathrm{j}}\right) \cdot \mathrm{C}_{\mathrm{j}}}$

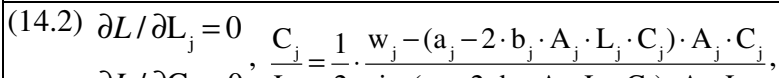

$\partial L / \partial C_{j}=0, \frac{L_{j}}{2}=\frac{1}{i-\left(a_{j}-2 \cdot b_{j} \cdot A_{j} \cdot L_{j} \cdot C_{j}\right) \cdot A_{j} \cdot L_{j}}$

$L_{j}=\frac{a_{j}}{3} \cdot \frac{a_{j} / 3+\sqrt{\left(a_{j} / 3\right)^{2}-b_{j} \cdot\left(i \cdot w_{j} / A_{j}\right) /\left(a_{j} / 3\right)}}{b_{j} \cdot w_{j}}, C_{j}=\frac{w_{j} / A_{j}}{a_{j} / 3}$

(14.3)

$X_{j}=\frac{a_{j} / 3+\sqrt{\left(a_{j} / 3\right)^{2}-b_{j} \cdot\left(i \cdot w_{j} / A_{j}\right) /\left(a_{j} / 3\right)}}{b_{j}}$, while $\frac{a_{j} / 3}{b_{j}}<X_{j}<2 \cdot \frac{a_{j} / 3}{b_{j}}$,

$\frac{\partial X_{j}}{\partial A_{j}}=X_{A j}^{\prime}=\frac{1}{2 \cdot\left(a_{j} / 3\right)} \cdot \frac{i \cdot w_{j} / A_{j}^{2}}{b_{j} \cdot X_{j}-a_{j} / 3}>0$,

$\frac{\partial^{2} X_{j}}{\partial A_{j}^{2}}=-\frac{i \cdot w_{j}}{\left(a_{j} / 3\right) / b_{j}} \cdot \frac{X_{j}-\left(a_{j} / 3\right) / b_{j}+A_{j} / 2}{\left(b_{j} \cdot X_{j}-a_{j} / 3\right)^{2} \cdot A_{j}^{3}}<0$

$(14.4)$

$\mathrm{U}_{\mathrm{j}}=\frac{\mathrm{a}_{\mathrm{j}} / 3}{\mathrm{w}_{\mathrm{j}}} \cdot\left[\frac{\left(\mathrm{a}_{\mathrm{j}} / 3\right)+\sqrt{\left(\mathrm{a}_{\mathrm{j}} / 3\right)^{2}-\mathrm{b}_{\mathrm{j}} \cdot\left(\mathrm{i} \cdot \mathrm{w}_{\mathrm{j}} / \mathrm{A}_{\mathrm{j}}\right) /\left(\mathrm{a}_{\mathrm{j}} / 3\right)}}{\mathrm{b}_{\mathrm{j}}}\right]^{2}$

Public firms in region $\mathrm{j}$ are co-coordinated by a trust headquarters (c.f. Table 2). The headquarters maximizes its utility by allocating total budget $\mathrm{D}$ to finance fixed costs $\mathrm{K}_{\mathrm{Fj}}$, which are expressed by $\mathrm{Aj}\left(\mathrm{s}_{\mathrm{j} 1}, \mathrm{~s}_{\mathrm{j} 2}\right)$ and are equal to $\mathrm{D}_{\mathrm{j}}-\mathrm{D}_{\mathrm{j}}$ adds up to total budget $\mathrm{D}$ (equation 16). The utility of the trust of public firms is linked to the 
outputs of the public firms. The parameters characterizing the headquarters are not directly location dependent. Through the output of the public firms, the budget allocation solution for the headquarters depends indirectly on the selection of a location for the public firms. The resulting budget split is shown in equations (17) and (18) in Table 2 and graphically depicted in Figure 13.

Table 2. Equations related to the headquarter of the public firms trust

(15) Utility

$W=\sum_{j=1}^{2} \alpha_{j} \cdot X_{j}$ with $\alpha_{j}$ : evaluation parameter of output of public firm $j$

(16) Total budget

$\mathrm{D}=\sum_{\mathrm{j}=1}^{2} \mathrm{D}_{\mathrm{j}}=\sum_{\mathrm{j}=1}^{2} \mathrm{~K}_{\mathrm{Aj}}=\sum_{\mathrm{j}=1}^{2} \mathrm{~A}_{\mathrm{j}}$

(17) Utility maximization

Max! $W=\sum_{j=1}^{2} \alpha_{j} \cdot X_{j}$, while $D=\sum_{j=1}^{2} A_{j}$,

$X_{j}=\left[a_{j} / 3+\sqrt{\left(a_{j} / 3\right)^{2}-b_{j} \cdot\left(i \cdot w_{j} / A_{j}\right) /\left(a_{j} / 3\right)}\right] / b_{j} ;$

Lagrange-Function: $L=\sum_{j=1}^{2} \alpha_{j} \cdot X_{j}+\lambda \cdot\left(D-\sum_{j=1}^{2} A_{j}\right)$

$\partial \mathrm{L} / \partial \mathrm{A}_{\mathrm{j}}=\alpha_{\mathrm{j}} \cdot \mathrm{X}_{\mathrm{Aj}}^{\prime}-\lambda=0, \forall \mathrm{j}$,

$\frac{\mathrm{A}_{1}}{\mathrm{~A}_{2}}=\sqrt{\frac{\alpha_{1}}{\alpha_{2}} \cdot \frac{\mathrm{w}_{1} / \mathrm{a}_{1}}{\mathrm{w}_{2} / \mathrm{a}_{2}} \cdot \sqrt{\frac{\left(\mathrm{a}_{2} / 3\right)^{2}-\mathrm{b}_{2} \cdot\left(\mathrm{i} \cdot \mathrm{w}_{2} / \mathrm{A}_{2}\right) /\left(\mathrm{a}_{2} / 3\right)}{\left(\mathrm{a}_{1} / 3\right)^{2}-\mathrm{b}_{1} \cdot\left(\mathrm{i} \cdot \mathrm{w}_{1} / \mathrm{A}_{1}\right) /\left(\mathrm{a}_{1} / 3\right)}}}=$

$\sqrt{\frac{\alpha_{1}}{\alpha_{2}} \cdot \frac{w_{1} / a_{1}}{w_{2} / a_{2}} \cdot \frac{b_{2} \cdot X_{2}-a_{2} / 3}{b_{1} \cdot X_{1}-a_{1} / 3}}$

(18) Budget allocation

$\mathrm{F}\left(\mathrm{A}_{1}, \mathrm{~A}_{2}\right)=\frac{\mathrm{A}_{1}^{2}}{\mathrm{~A}_{2}^{2}}-\frac{\alpha_{1}}{\alpha_{2}} \cdot \frac{\mathrm{w}_{1} / \mathrm{a}_{1}}{\mathrm{w}_{2} / \mathrm{a}_{2}} \cdot \frac{\mathrm{b}_{2} \cdot \mathrm{X}_{2}-\mathrm{a}_{2} / 3}{\mathrm{~b}_{1} \cdot \mathrm{X}_{1}-\mathrm{a}_{1} / 3}=0$, while $\mathrm{D}=\mathrm{A}_{1}+\mathrm{A}_{2}$,

$\frac{\mathrm{dF}}{\mathrm{dD}}=\frac{\partial \mathrm{F}}{\partial \mathrm{A}_{1}} \cdot \frac{\mathrm{dA}_{1}}{\mathrm{dD}}+\frac{\partial \mathrm{F}}{\partial \mathrm{A}_{2}} \cdot \frac{\mathrm{d}\left(\mathrm{D}-\mathrm{A}_{1}\right)}{\mathrm{dD}}=\frac{\partial \mathrm{F}}{\partial \mathrm{A}_{1}} \cdot \frac{\mathrm{dA}_{1}}{\mathrm{dD}}+\frac{\partial \mathrm{F}}{\partial \mathrm{A}_{2}} \cdot\left(1-\frac{\mathrm{dA}_{1}}{\mathrm{dD}}\right)=0$,

$\frac{\mathrm{dA}_{1}}{\mathrm{dD}}=\mathrm{A}_{\mathrm{D} 1}^{\prime}=\frac{-\partial \mathrm{F} / \partial \mathrm{A}_{2}}{\partial \mathrm{F} / \partial \mathrm{A}_{1}-\partial \mathrm{F} / \partial \mathrm{A}_{2}}>0, \frac{\mathrm{dA}_{2}}{\mathrm{dD}}=\mathrm{A}_{\mathrm{D} 2}^{\prime}=1-\frac{\mathrm{dA}_{1}}{\mathrm{dD}}=\frac{\partial \mathrm{F} / \partial \mathrm{A}_{1}}{\partial \mathrm{F} / \partial \mathrm{A}_{1}-\partial \mathrm{F} / \partial \mathrm{A}_{2}}>0$,

while $\frac{\partial \mathrm{F}}{\partial \mathrm{A}_{1}}=\frac{\mathrm{A}_{1}^{2}}{\mathrm{~A}_{2}^{2}} \cdot\left[\frac{2}{\mathrm{~A}_{1}}+\frac{\mathrm{X}_{\mathrm{Al}}^{\prime}}{\mathrm{X}_{1}-\left(\mathrm{a}_{1} / 3\right) / \mathrm{b}_{1}}\right]>0, \frac{\partial \mathrm{F}}{\partial \mathrm{A}_{2}}=-\frac{\mathrm{A}_{1}^{2}}{\mathrm{~A}_{2}^{2}} \cdot\left[\frac{2}{\mathrm{~A}_{2}}+\frac{\mathrm{X}_{\mathrm{A} 2}^{\prime}}{\mathrm{X}_{2}-\left(\mathrm{a}_{2} / 3\right) / \mathrm{b}_{2}}\right]<0$

The owner government of the public trust maximizes votes. In this way it establishes an optimal total budget (Table 3, and equations (19), (20), (21), Figure 14), which is determined by:

- Features of the production functions

- Features of the demand functions 
- Preferences of the utility functions of the management of public firms, and of the management of the headquarters

- Vote maximization of the owner government

- Voter preferences and voting behaviour

- Factor prices

- Location dependence of voters and of the fixed costs of the public firms

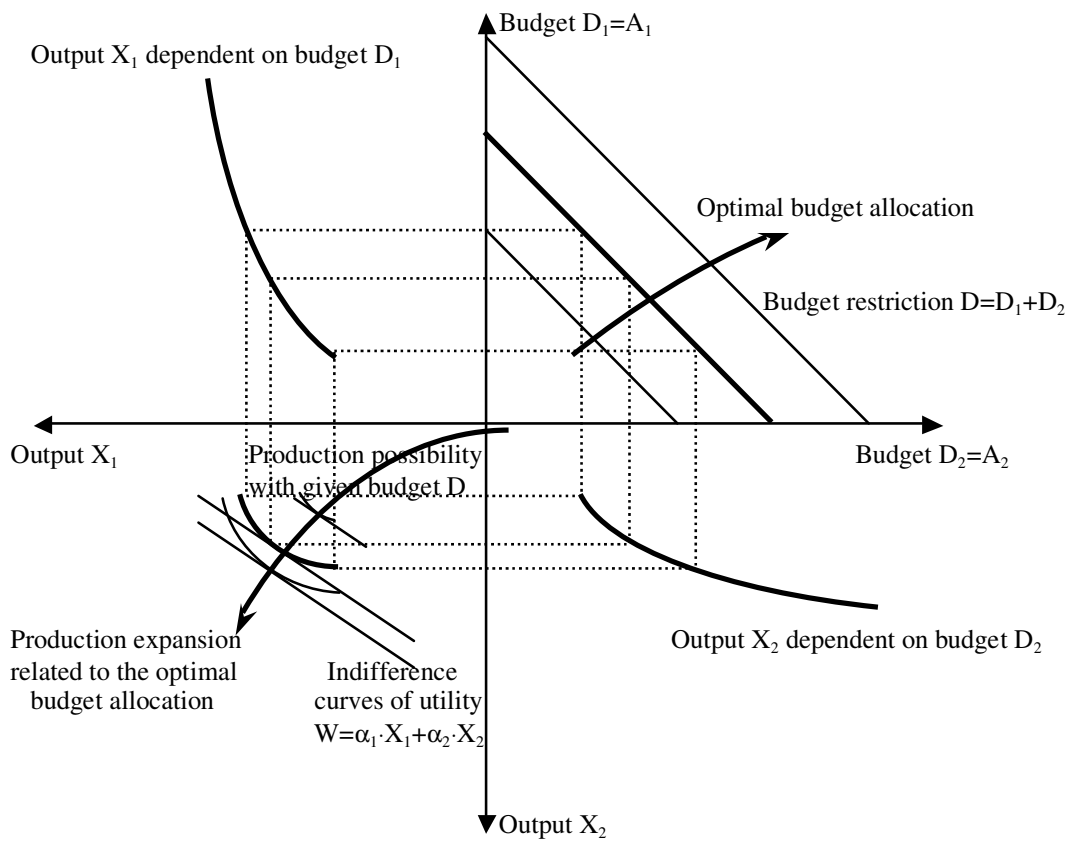

Figure 13. Allocation of budgets by the trust headquarters (compiled by the authors).

The optimal budget and implicitly the optimal locations are shown in Table 3 . When concentrating on location-dependent fixed costs, the basic proposals mentioned above hold for a public firm. When we emphasize changes in distance depending votes, the solutions change. Through location-dependent votes, the solution is pulled to points of high vote sensitivity. The following propositions with respect to public firm 1 , result.

\section{(1) If no voters sensitivity changes:}

The marginal changes due to production and budget adjustments are the same in either direction (c.f. Table 3: the third and fourth term in equation (21)). 
Table 3. Equations concerning the public trust in the public owner

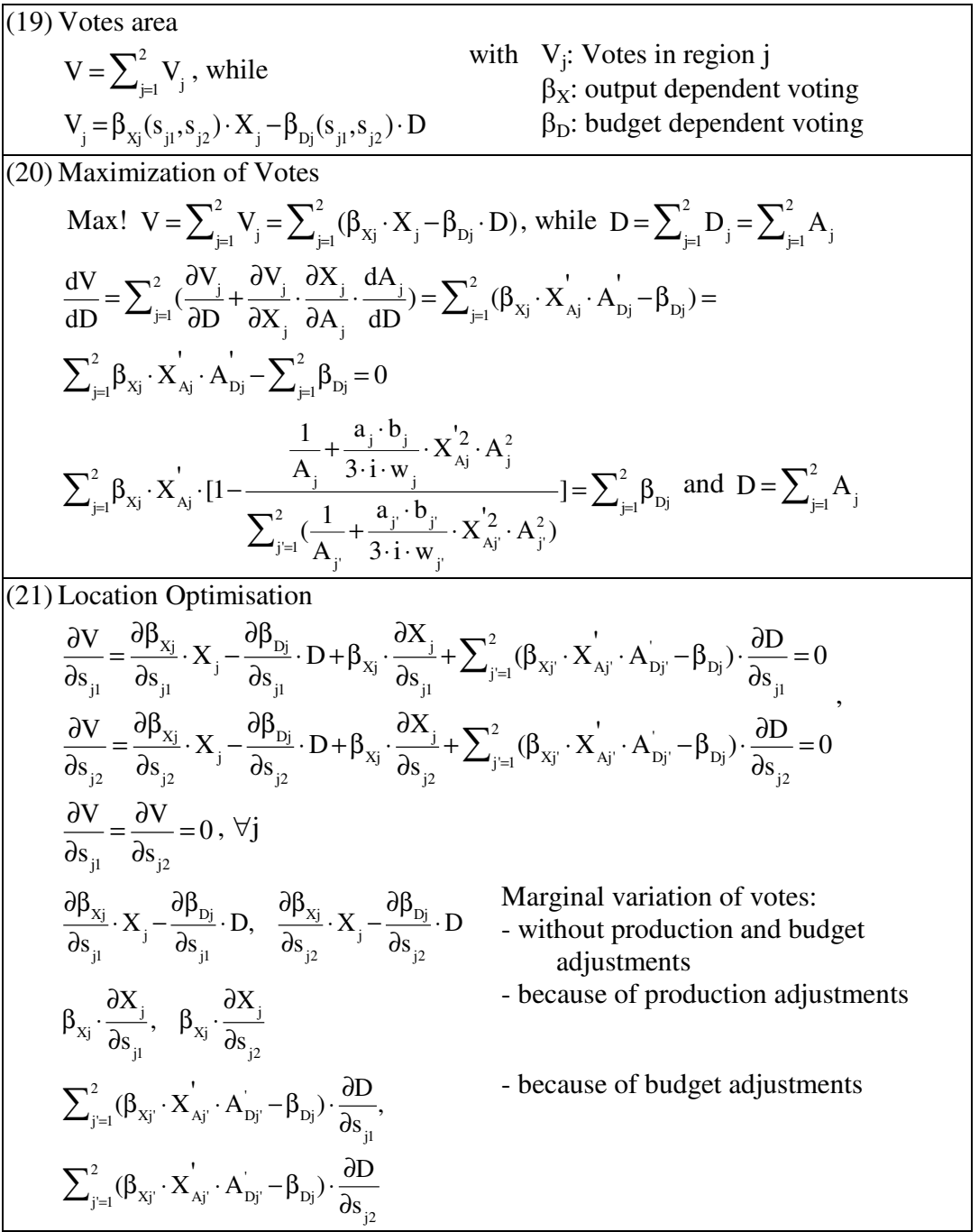

(2) If only location output sensitive votes change:

Marginal changes in votes due to production and budget adjustments as well as votes changes due to marginal output votes and the resulting adjustments being the same in each direction.

(3) If budget and output sensitive votes change: 
Marginal changes in votes induced by the sensitivity changes as well as due to output and budget changes having to be equal in all directions.

The same is true for public firm 2 .

Thus a theory of public firm location is formulated by integrating several of the location theories mentioned earlier. The vote maximal budget is shown in Figure 14. The vote maximal total results when the marginal increase in output dependent votes absolutely equals the marginal decrease in budget dependent votes.

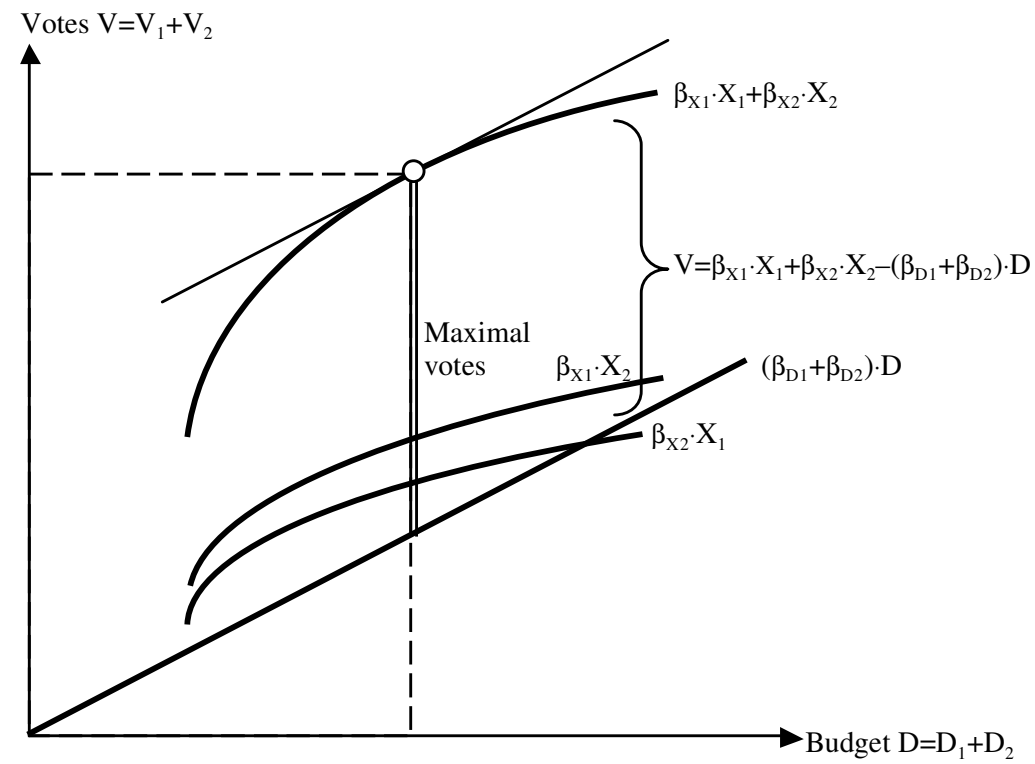

Figure 14. Vote maximal total budget (compiled by the authors).

\section{Conclusions and further research development}

The decision oriented theory of the public firm (Feng, Friedrich 2013) becomes extended. The authors consider that sometimes public firms compete horizontally as well. This can be due to competition among the public owners (e.g. municipalities) considering location choices for public firms they own, or public firms competing against each other. We mention some results related to the first type of competition and we refer to how the literature on location choices under oligopolic conditions could be referred to within the framework of our basic approach. One approach by Cornes and Hartley (2001) also allows modelling the establishment of joint ventures and their location choices. 
The basic model of the public firm is used to provide insight into the location choices of a trust of public firms. The trust exhibits coordination at three levels via the politically-oriented decision-making body of the public owner, the trust's headquarters and subsidiary public firms. The resulting model illustrates the interplay of different decision-makers and the effects of the coordinating activities. The first attempts to formulate a public firm decision-making oriented location theory exist.

The microeconomic public firm trust location model and location theories provided can be extended in various ways:

- More public firms, different types of public firms and several trusts can also be introduced;

- More competitive parameters of actions could be considered for public firms;

- Different market forms and private-public competition among firms can be integrated;

- Different vote functions for federal, state and local governments should be introduced;

- Competition among governments on one side and their public firms could be involved (Lindemann 1999);

- A set of horizontal and vertical competition models to explain and predict competition for investor settlement (in China), developed by Feng (2005), could be linked to these approaches;

- Other location theories concerning growth, development, growth pole and cluster theory and infrastructure theories, could be adapted for the purposes of public firm location theory.

\section{References}

1. Armstrong, M. (1996) Multiproduct Nonlinear Pricing, Econometrica, Vol. 64, pp. 51-75

2. Bernheim, D., D. Whinston (1986) Menu Auctions, Resource Allocation and Economic Influence, Quarterly Journal of Economics, Vol. 101, pp. 1-31

3. Cornes, R., R. Hartley (2001); Joint Production and Share Functions, Working Paper, Department of Economics, Keele University, Keele

4. Feng X. (2005), Theorie der unternehmerischen Standortwahl, des Standortwettbewerbs und raumwirtschaftlicher Effekte, Manuskript, München.

5. Fgng X., P. Friedrich (2013), Basic Approaches to a Location Theory of One Public Firm,

6. Frey, B.S., F. Oberholzer-Gee (1996), Fair siting Procedures: An Empirical Analysis of their Importance and Characteristics, Journal of Policy Analysis and Management, Vol. 15, pp. 353-376

7. Frey, B.S., F. Oberholzer-Gee, R. Eichenberger (1996), The Old Lady Visits your Backyard: A Tale of Morals and Markets, Journal of Political Economy, Vol. 104, pp. 1297-1313

8. Friedrich, P. (1969), Investitionskriterien für Gemeindeunternehmen, Mohr, Tübingen 
9. Friedrich, P. (1976), Standorttheorie für öffentliche Verwaltungen, Nomos, Baden-Baden

10. Friedrich, P. (1988), X-Ineffizienz öffentlicher Unternehmen - ein ausschlaggebendes Privatisierungsargument?, in: H.Brede (Ed.), Privatisierung und die Zukunft der öffentlichen Wirtschaft, Nomos, Baden-Baden, pp. 235-265

11. Friedrich, P. (1998), Gebührensteuerung mittels geeigneter Kostenrechnung Ein Analyserahmen - , in: H. Brede (Ed.), Preise und Gebühren in der Entsorgungswirtschaft, Nomos, Baden-Baden, pp. 181-220

12. Grimsey, D: Lewis, M.K. (2004), Public Private Partnerships, The Worldwide Revolution in Infrastructure Provision and Project Finance, Elgar, Cheltenham, Northampton

13. Ingberman, D.E. (1995), Siting noxious facilities are market efficient? Journal of Environmental Economics and Management, Vol. 29, pp. S20-S33

14. Isard W., T.E. Smith, Isard P., T.H. Tung, M. Dacey (1986), General theory, Social, Political, Economic and Regional, MIT-Press, Cambridge Mass., London

15. Jehiel, P., B. Moldovanu (1996), Strategic Nonparticipation, Rand Journal of Economics, Vol. 27, pp. 84-98

16. Jehiel, P., B. Moldovanu, E. Stachetti (1999), Multidimensional Mechanism Design for Auctions with externalities, Journal of Economic Theory, Vol. 85, pp. 258-293

17. Krelle, W. (1976), Preistheorie, II. Teil, Mohr, Tübingen

18. Kuhnreuther, H., P, R. Kleindorfer (1986), A Sealed-bid Auction Mechanism for Siting Noxious Facilities, American Economic Review, Vol. 76, pp. 295-299

19. Kuhnreuther, H., P.R. Kleindorfer, P.J: Knez, R. Yasick (1987), A Compensation Mechanism for Siting Noxious Facilities: Theory and Experimental Design, Journal of Environmental Economics and Management, Vol. 14, pp. 371-383

20. Lindemann, S. (1999), Theorie und Empirie kommunalen Wirtschaftsförderungs-wettbewerbs, Nomos, Baden-Baden

21. McAfee, R.P., J. McMillan (1988), Multidimensional Incentive Compatibility and Mechanism Design, Journal of Economic Theory, Vol. 46, pp. 335-354

22. McAfee, R.P., J. McMillan, M.D. Whinston (1989), Multiproduct Monopoly, Commodity Bundling, and Correlation of Values, Quarterly Journal of Economics, Vol. 104, pp. 371-383

23. Mueller D.C. (2002), Public Choice III, Cambridge University Press, Cambridge

24. Richardson, J., Kunreuther H. (1993), Essential test for a Nash-efficient Mechansim for Collective Choice with Compensation, Journal of Behavior and Organization, Vol. 22, 349-369

25. Rochet, J.C., P. Choné (1998), Ironing, Sweeping, and Multidimensional Screening, Econometrica, Vol. 66, pp. 783-826

26. Waehrer, K. (2003), Harzardous Facility Siting when Cost Information is Private: An Application of Multidimensional Mechanism Design, Journal of Public Economy Theory, Vol. 5, pp. 605-622 


\title{
EIN STANDORTMODELL FÜR EINEN KONZERN ÖFFENTLICHER UNTERNEHMEN
}

\author{
Xiao Feng ${ }^{1}$, Peter Friedrich ${ }^{2}$ \\ Tongji-Universität, Universität Tartu
}

In Europa gibt es mehrere Konzerne öffentlicher Unternehmen. In einem Beitrag zur Standorttheorie öffentlicher Unternehmen - siehe Standorttheorie öffentlicher Unternehmen im Band: Estnische Gespräche über Wirtschaftspolitik: Wirtschaftspolitische Theorie und Praxis in der Europäischen Union, 2013, Nr.1, "Grundlegende Ansätze zur Standortheorie eines öffentlichen Unternehmens“ haben die Autoren auf die mannigfaltigen Standortfaktoren öffentlicher Unternehmen verwiesen und Standorttheorien für öffentliche Unternehmen diskutiert und entwickelt. Die Standortfaktoren beinhalten ökonomische, betriebswirtschaftliche, geographische, planerische Gegebenheiten, welche die öffentlichen Unternehmen und ihre Umwelt betreffen, aber auch ökonomische, betriebliche, gesellschaftliche und politische Ziele sowie die Zahl der beteiligten Entscheidungsträger. Eine Integration dieser Theorien zu einem Modell für einen Konzern öffentlicher Unternehmen wird in diesem Beitrag versucht.

Der Konzern ist dreistufig aufgebaut (siehe Abbildung 1). Ein öffentlicher Eigentümer bestimmt die Grundlagen der Unternehmenspolitik, indem er über die Höhe des gesamten Investitionsbudgets entscheidet. Seine grundlegende Unternehmenspolitik ist auf das Ziel der Machterhaltung über Wahlerfolge ausgerichtet. Ferner existiert eine Holding, die in unserer vereinfachten Modellwelt, die Investitionsbudgets $\mathrm{Dj}$ der Firmen $\mathrm{j}$ und damit die fixen Kosten $\mathrm{Aj}$ (sie gleichen $\mathrm{K}_{\mathrm{Fj}}$ ) der dem Konzern angehörigen öffentlichen Unternehmen $\mathrm{j}$ festlegt. Die Tochterfirmen produzieren Güter $\mathrm{X}_{\mathrm{j}}$, welche an Abnehmer in Regionen $\mathrm{j}$ geliefert werden. Somit wird der Konzern finanziell koordiniert. Die Wähler ihrerseits reagieren auf Leistungszunahmen seitens eines öffentlichen Unternehmens $\mathrm{j}$ in Region $\mathrm{j}$ zustimmend positiv. Allerdings befürchten sie Nachteile aus hohen Investitionsbudgets, die finanziert werden müssen und zu deren Finanzierung D sie letztlich beizutragen haben. Der öffentliche Eigentümer berücksichtigt diese Reaktionen bei der Festlegung des gesamten Investitionsbudgets.

Die Unternehmen befinden sich an Standorten mit den Koordinaten $\mathrm{s}_{11}$ und $\mathrm{s}_{12}$ für Unternehmen 1 in Region 1 und mit den Koordinaten $\mathrm{s}_{21}$ und $\mathrm{s}_{22}$ für Unternehmen 2 in Region 2. Die Firmen streben einen hohen Output und eine hohe Beschäftigung an. Eine Produktionsfunktion zeigt jeweils die Abhängigkeit zwischen dem Output

\footnotetext{
${ }^{1}$ Prof. Dr. Xiao Feng, director of Sino-German College of Applied Sciences (CDHAW), Training Building, Jiading Campus, Tongji University, 4800 Cao An Highway, Shanghai, P. R.China (201804), Tel. 0086 (0)21 6958 4732, Fax $00 \quad 86 \quad(0) 216958$ 9621, fengxiao@tongji.edu.cn

${ }^{2}$ Prof. Dr. Dr. h.c. Peter Friedrich, senior researcher, Faculty of Economics and Business Administration, University of Tartu, Narva Rd. 4, 51009 Tartu, Estonia, Tel. 00372 7376333, Fax 003727376327, Peter@mtk.ut.ee
} 
und den Investitionen, d.h. dem Kapitaleinsatz, dem Arbeits- und dem Materialeinsatz auf. Der Wert des Kapitaleinsatzes entspricht den Investitionen (Fixkosten als Abschreibungen). Sie werden vom Eigentümer finanziert. Die variablen Kosten erwirtschaftet das öffentliche Unternehmen selbst. Der Lohnsatz differiert je nach Standort Es existiert eine Preisabsatzfunktion und das jeweilige öffentliche Unternehmen setzt seinen Preis selbst. Die Funktionen sind in Abbildung 1 aufgeführt.

Die Maximierung des Nutzens des Unternehmensmanagements bei Berücksichtigung der Selbstfinanzierungsanforderung erlauben die folgenden Feststellungen zur optimalen Standortwahl. Die Relation der Veränderungen der standortabhängigen fixen Kosten bei Verschiebung des Standortes in Richtung1 und Richtung 2 gleichen der folgenden Relation. Es handelt sich um das Verhältnis aus der Veränderung des Lohnsatzes abzüglich der marginalen Arbeitskosten multipliziert mit dem Wertgrenzprodukts bei Verschiebung des Standortes in Richtung 1 zur Veränderung des Lohnsatzes abzüglich der Veränderung der Arbeitskosten multipliziert mit dem Wertgrenzprodukt bei Verschiebung des Standortes in Richtung 2. Ferner gleicht das Verhältnis der Nutzenänderungen bei Verschiebung des Standortes in Richtung 1 und Richtung 2 dem Verhältnis der Bruttogrenzgewinne bei diesen Verschiebungen. Die variablen Durchschnittskosten entsprechen dem Preis. Diese Aussagen gelten für beide Unternehmen.

Die Holdingfirma koordiniert die beiden Unternehmen, indem sie das gesamte Investitionsbudget $D$ auf die beiden Unternehmen aufteilt $\left(D=\sum_{j=1}^{2} A_{j}\right)$. Der Nutzen der Holding, z.B. die Erreichung ihrer öffentlichen Ziele, ist abhängig von den Outputs der Unternehmen 1 und 2. Obwohl die Parameter in den Gleichungen für die Holding nicht direkt von ihrem Standort abhängen wird der Nutzen der Holding über die standortwahlbedingten Änderungen des Outputs der Unternehmen 1 und 2 beeinflusst. Für die Holding ergibt sich die günstigste Budgetaufteilung, wenn der Grenznutzen der Outputs ausgelöst von Fixkostenänderungen verbunden mit der Standortwahl für beide Unternehmen für die Holding gleich groß wird.

Allerdings wird das Gesamtbudget, das die Holding zuweisen kann, vom Wählerverhalten in den Regionen bestimmt, da der Konzerneigner Wählerzustimmung maximiert. Die Wähler reagieren zustimmend und standortabhängig auf Erhöhungen der Ausbringungsmengen. Aber auch ablehnend und standortabhängig auf vermutete Finanzierungsbelastungen, die mit der Höhe des Gesamtbudgets verbunden sind. Aus der Maximierung der Wählerstimmen seitens des Eigentümers resultiert ein günstigstes Budget im Sinne des Konzerneigners. Das Optimalbudget wird erreicht, wenn der Zuwachs an outputabhängigen Stimmen der Abnahme an budgetabhängigen Stimmen gleicht. 


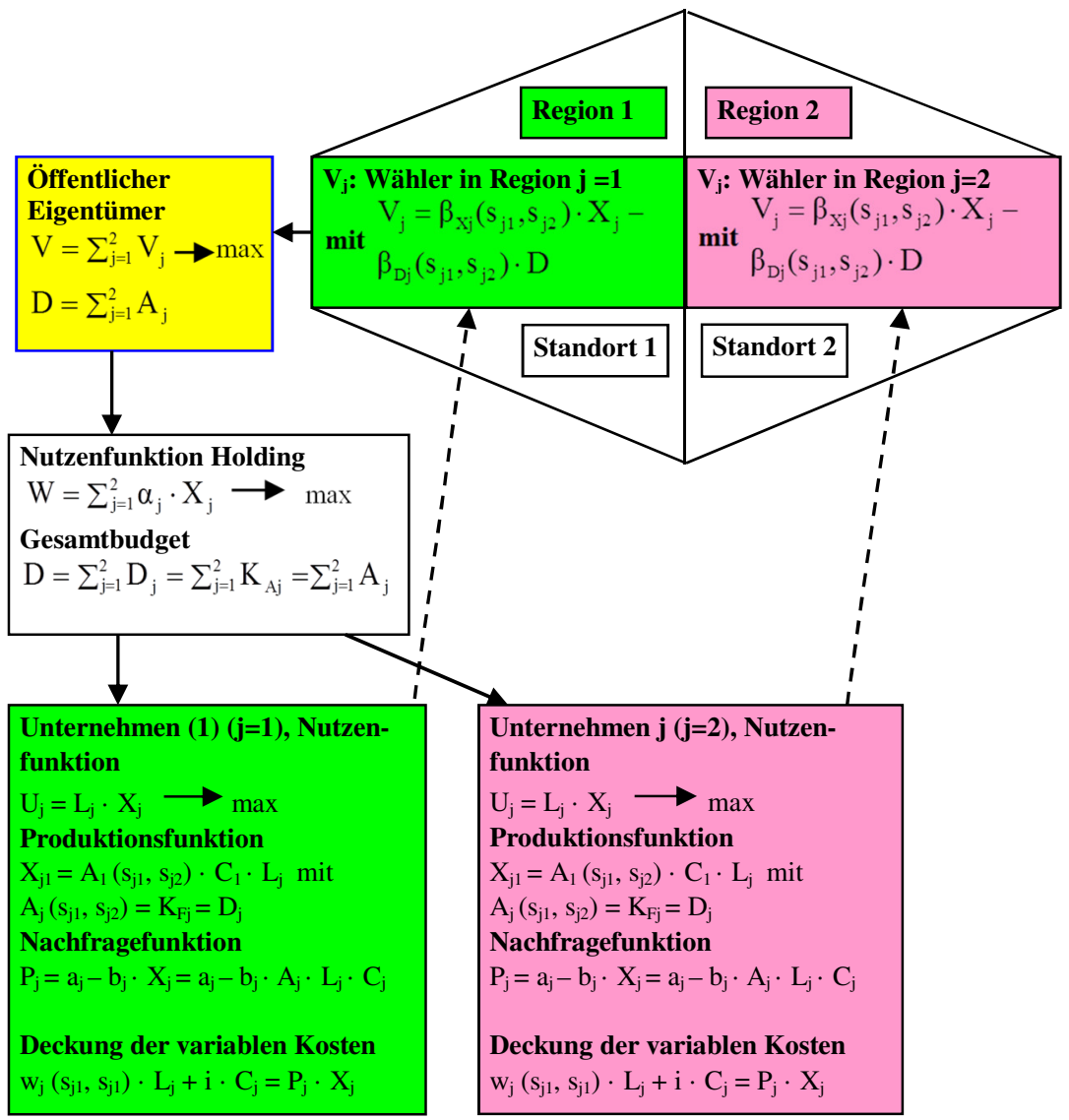

Abbildung 1: Öffentlicher Konzern, Quelle: von den Autoren skizziert.

Dieses Optimalbudget wird beeinflusst von den:

- Eigenheiten der Produktionen,

- Charakteristika der Nachfragefunktionen,

- Präferenzen der Nutzenfunktionen des Managements der öffentlichen Unternehmen und jener der Holding,

- Stimmenmaximierungswünschen des öffentlichen Eigentümers,

- Wählerwünschen und dem Wählerverhalten,

- Faktorpreisen und deren Standortabhängigkeit,

- Standortpräferenzen der Wähler und der Standortabhängigkeit der fixen Kosten der Unternehmen. 
Die obigen Aussagen gelten, soweit wir nur die standortabhängigen fixen Kosten (Investitionen) betrachten, für Unternehmen1 und Unternehmen 2. Die marginalen Änderungen der Produktion und marginale Budgetänderungen gleichen sich in beide Richtungen für Unternehmen1. Werden die Wählersensibilitäten einbezogen, so ändern sich die Ergebnisse. Die Lösung tendiert zu Standorten mit hoher Wählersensibilität. Falls sich nur das outputsensible Verhalten ändert, müssen die outputabhängigen Stimmenänderungen und solche aufgrund der Budgetänderungen plus solche aufgrund der marginalen Outputänderung in beiden Richtungen gleich groß sein. Wenn sich sowohl outputsensible als auch budgetsensible Verhalten ändern, müssen die outputabhängigen Stimmenänderungen und die budgetabhängigen Stimmenänderungen als auch die marginalen Stimmenänderungen aufgrund der Output- und der Budgetvariation in beiden Richtungen gleich groß sein. Diese Ergebnisse gelten wiederum für Unternehmen 1 und Unternehmen 2.

Das Modell kann auch Konzerne einbeziehen, die teilweise unbeliebte Unternehmen aufweisen, z.B. Mülldeponien, Atomend- oder -zwischenlager, Wasserschutzgebiete, oder solche, welche die Wähler gerne in ihrer Nähe haben, z.B. kulturelle Einrichtungen. In diesem Modell sind die angenommenen Funktionen well-behaved. Falls dies nicht der Fall ist, etwa Sprünge in den Funktionen vorkommen oder nur diskrete Werte existieren, hat man nach guten Lösungen mit Hilfe von Methoden des Operations-Research oder mit Hilfe von Heuristiken zu suchen. Jedoch ändern sich die grundlegenden Optimalbedingungen nicht. Erste Versuche eine Standorttheorie für öffentliche Unternehmen $\mathrm{zu}$ entwickeln, wurden hier um ein Standortmodell für einen Konzern ergänzt.

Dieses Modell kann in mehrfacher Hinsicht Erweiterungen erfahren:

- Weitere und verschiedene Unternehmen sowie differierende Konzerne können einbezogen werden.

- Weitere Konkurrenzaktionsparameter lassen sich einbeziehen, z.B. Lieferzeiten, Kreditierungen, Qualitäten, vorgeschriebene Tarifformen.

- Verschiedene Marktformen und privat-öffentlicher Wettbewerb mögen Berücksichtigung finden,

- Die Standortwahl für die Holding, z.B. Abhängigkeiten vom Standort des Eigentümers, den Entfernungen $\mathrm{zu}$ den Tochterunternehmen, Beziehungsnetzwerke, ist noch zu modellieren..

- Verschiedene Wahlfunktionen für Bundesstaatliche, Länderwahlen oder Gemeindewahlen könnten in das Modell aufgenommen werden (Feig, Friedrich, 2002). Die Konkurrenz zwischen Eigentümern (mehreren Bundesländer, Gemeinden) und zwischen zugehörigen Unternehmen bzw. Konzernen (z.B. Flughäfen, Opern) mag man einbeziehen.

- Verschiedene horizontale und vertikale Wettbewerbsmodelle die beispielsweise für regionale Investitionen in der VR China von Feig (2006) entwickelt worden sind, lassen sich mit dem Konzernmodell kombinieren. 